\title{
INOVASI PELAYANAN PUBLIK DALAM MENGHADAPI ERA REVOLUSI INDUSTRI 4.0 DI KOTA BANDUNG
}

\author{
Riki Satia Muharam \\ Ilmu Administrasi Publik STIA Cimahi \\ riki.satiam@gmail.com \\ Fitri Melawati \\ Ilmu Administrasi Publik STIA Cimahi \\ fitrimelawati@ymail.com
}

\begin{abstract}
Abstrak
Semakin canggihnya perkembangan dalam teknologi, dunia memasuki apa yang dinamakan era revolusi industry 4.0, penekanan pada pola digital economy, intelligence, robotic, big data dan dikenal sebagai fenomena dari disruptive innovation, hal ini menjadikan kota menghadapi tantangan yang semakin kompleks. Jumlah penduduk yang bertambah maupun migrasi menjadi pemicu berbagai permasalahan dalam ekonomi, sosial, budaya dan keamanan. Masyarakat semakin kritis dan menginginkan pelayanan dari pemerintah kota semakin maksimal, namun tidak didukung oleh sumber daya yang ada. Inovasi sebagai proses dan/atau hasil dari pengembangan pengetahuan, pengalaman dan keterampilan dalam memperbaiki atau menciptakan produk baik jasa maupun barang, proses, dan/atau pembaharuan sistem memberikan arti dari sebuah nilai secara signifikan. Pemerintah Kota Bandung memiliki banyak inovasi dalam memberikan Pelayanan Publik, melalui paper ini menjelaskan Bagaimana inovasi-inovasi pelayanan publik di Kota Bandung menghadapi era revolusi industri 4.0.
\end{abstract}

Kata Kunci : Inovasi, Pelayanan, Publik, Kota Bandung.

\begin{abstract}
.
The development of increasingly sophisticated technology, the world is now entering industrial revolution 4.0 era, which emphasizes on artificial intelligence, the digital economy pattern, , robotic, big data, etc. or known as the disruptive innovation phenomenon, this makes the city face increasingly complex challenges. Natural population growth and migration also trigger the emergence of various economic, social, cultural and security problems. The community demands services that are increasingly maximized by the city administration, while the resources they possess often do not support. Innovation can be defined as the process and/or results of the development of the use of knowledge, skills and experience in creating or improving products in the form of new goods or services, processes and/or systems that can provide significant value significantly. The Bandung City Government has many innovations in providing Public Services, through this paper explains how public service innovations in the face of the industrial revolution era 4.0. in Bandung City.
\end{abstract}

\section{Key Word: Innovation, Public Service, Bandung City}




\section{Pendahuluan}

Semakin berkembang dan semakin canggih nya teknologi, mengakibatkan dunia menghadapi apa yang dinamakan era dalam revolusi industri 4.0. Penekanannya pada pola digital economy, robotic, big data, intelligence menjadi fenomena disruptive innovation. Hal ini menjadikan kota menghadapi tantangan yang semakin kompleks. Migrasi maupun pertambahan penduduk menjadi pemicu permasalahan baik itu ekonomi, sosial, budaya, dan keamanan. Masyarakat menuntut pemerintah kota memberikan pelayanan prima, namun disisi lain tidak didukung oleh sumber daya yang ada.

Pelayanan prima yang berkualitas, bermutu tinggi menjadi fokus perhatian organisasi publik. Keterbukaan informasi, berkaitan dengan pelayanan mendorong kesadaran masyarakat tentang kewajiban dan haknya. Oleh karena itu, harapan untuk mendapatkan pelayanan prima dibebankan kepada organisasi public (Agus Prianto, 2006), birokrasi menentukan baik tidaknya dari pelayanan publik yang diselenggarakan. Kondisi birokrasi memberikan iklim tersendiri bagi terselenggaranya pelayanan publik yang optimal. Pelayanan publik yang optimal belum dapat direalisasikan di Indonesia. Di Indonesia pelayanan publik yang baik belum dapat terealisasi, masih rendah kondisi pelayanan publik di Indonesia. Inovasi sector publik diperlukan dalam pengembangan pelayanan. Kehadiran inovasi sebagai produk yang relative baru dan sifatnya menggantikan caracara yang lama, artinya pelayanan public prinsipnya memuat inovasi baru.

\section{Tinjauan Pustaka}

\subsection{Hakekat Pelayanan Publik}

Public service menjadi tugas utama setiap instansi dalam pemerintahan untuk mewujudkan kesejahteraan (public welfare). Tampubolon (2001:139-141) mengartikan pelayanan sebagai, "Orang melakukan sesuatu kebaikan bagi orang lain... karena itu, seorang pelayan yang baik ialah "melayani, bukan dilayani". Sebagaimana, pendapat Zeithaml dkk (2006:4), pelayanan merupakan aktivitas ekonomi bukan sekedar produk fisik atau konstruksi secara umum, namun pelayanan bersifat tidak kasat mata atau tidak dapat dilihat.

Gabriel Roth (1991: 3) pelayanan merupakan "any service available to the public whether provided publicly (as a museum) or privately (as is a restaurant meal)". Menurut Roth pelayanan merupakan bentuk kegiatan pelayanan organisasi atau individu berupa jasa, barang kepada masyarakat baik kelompok maupun individu atau organisasi. Saefullah (2007:11) mendefinisikan pelayanan public sebagai kegiatan yang dilakukan pejabat, lembaga untuk memberikan pelayanan public, baik sifatnya langsung maupun tidak langsung.

Pelayanan publik (public service) oleh birokrasi publik adalah merupakan salah satu perwujudan dari fungsi aparatur negara sebagai abdi masyarakat di samping sebagai abdi negara. Eksistensi lembaga negara termasuk di dalamnya pada hakekatnya pelayan masyarakat, ia tidak dimaksudkan untuk melayani dirinya sendiri, namun untuk memberikan atau melayani masyarakat. Oleh karena itu, birokrasi publik berkewajiban dan bertanggung jawab untuk memberikan pelayanan publik yang baik dan profesional. Pelayanan publik oleh birokrasi merupakan 
perwujudan fungsi aparatur sebagai abdi negara dan abdi masyarakat. Eksistensinya dalam pelayanan masyarakat bukan melayani diri sendiri, tetapi melayani masyarakat, birokrasi public berkewajiban dan bertanggung jawab secara baik dan professional dalam memberikan pelayanan.

Dari pendapat para ahli atau pakar, dapat disimpulkan pelayanan public merupakan serangkaian kegiatan yang dilakukan oleh penyelenggara negara atau pemerintah, para pejabat, bentuknya berupa barang dan jasa, sifatnya langsung maupun tidak langsung sesuai dengan UndangUndang dan Peraturan-Peraturan.

\subsection{Old Public Administration}

Sebagai paradigma. Istilah administrasi sudah tidak pas lagi, karena perkembangan ilmunya berhenti pada tahun 1980an, bersifat klasik, tradisional. Baik istilahnya maupun kontennya sudah tidak cocok, sehingga harus dirubah menjadi management publik. Karena administrasi publik itu sendiri sejak kelahirannya terlalu berfokus pada strong government, artinya sector publik merupakan dominasi peran pemerintah dan pemerintah menjadi actor tunggal didalam menyelesaikan sector publik, dan kelahirannya administrasi publik dipelopori oleh Wilson.

Kelahirannya memberikan mandate kepada pemerintah, birokrasi untuk menyelesaikan masalah-masalah publik sebagai penerima mandate kebijakan administrasi publik. Artinya yang sifatnya kebijakan sampai teknis operasional harus disediakan oleh pemerintah. Tapi akibatnya dengan paradigm strong government fokus perhatian bagaimana menjadikan pemerintah menjadi kuat bersih, berwibawa, sehingga perhatian termasuk pembiayaan lebih banyak membiayai pembangunan birokratis sendiri, tahun 1970 ketika ada kelompok ASPA melakukan konferensi Tokohnya Carbelon dan juga para praktisi merasa prihatin terhadap perhatian akademisi terhadap kajian administrasi publik, mengapa yang diperhatikan ibirokrasi membangun birokrasi, dan hanya sebagian kecil saja biaya dipakai untuk pelayanan publik, padahal kehadiran birokrasi untuk melayani pelayanan publik secara maksimal. OPA terjebak mengurus internal saja.

\subsection{New Public Management (NPM)}

New Public Management (NPM) mulai berkembang di tahun 1980an di Australia, Amerika, New Zealand, dan Inggris akibat krisis dari negara kesejahteraan. Paradigma NPM menyebar luas karena adanya lembagalembaga internasional seperti IMF, Bank Dunia, Sekretariat Negara Persemakmuran maupun konsultan manajemen yang mempromosikannya.

Mengglobalnya NPM disebabkan juga oleh agen-agen perubahan seperti konsultan manajemen internasional, lembaga keuangan internasional maupun kantor-kantor akuntan, kesemuanya instrument dalam meningkatkan teknik manajemen baru sector private masuk ke sector public. Agen-agen perubahan ini berperan penting dalam mengimplementasikan teknik-teknik NPM.

Sistem pemerintahan yang berkembang dari setiap masa memiliki permasalahan masng-masing dimana selalu jatuh tidak efisiennya perilaku Birokrasi. Berbagai pemikiran mulai muncul untuk menemukan DNA terbaru sistem pemerintahan, mulai sifatnya tradisional menuju kondisi modern sesuai tuntutan jaman. Diawali dari OPA, bergeser menjadi NPM dimana 
konsep Reinventing Government (Osborn \& Gaebler) populer era 80-an sampai 90-an.

\subsection{New Public Service}

Paradigma New Public Management mendapatkan kritik dari Denhardt dan Denhardt, muncul instilah New Public Serivce. New Public Service Paradigm berakar dari beberapa teori tentang demokrasi, yang meliputi: Teori tentang demokrasi kewarganegaraan; pelibatan warganegara dan pentingnya deliberasi; Model masyarakat sipil dan komunitas; membangun social trust, jaringan sosial, kohesi sosial dalam pemerintahan yang demokratis; Teori administrasi negara baru dan organisasi humanis; fokus pada nilai-nilai kemanusiaan (human beings) dan respon terhadap keadilan, nilai-nilai kemanusiaan, isu-isu sosial lain; Administrasi negara postmodern yang mengutamakan dialog dalam memecahkan persoalan publik daripada menggunakan one best way perspective.

Denhardt dan Denhardt
merumuskan prinsip-prinsip NPS yang memiliki diferensiasi dengan prinsipprinsip OPA dan NPM. NPS mengajak pemerintah untuk : Serve Citizens, Not Customers; Seeks the Public Interest; Value Citizenship over Entrepreneurship; Think Strategically, Act Democratically; Recognize that accountability is not Simple; Serve Rather than Steer; Value People, Not Just Productivity (Melayani Warga Negara, bukan customer; Mengutamakan Kepentingan Publik; Kewarganegaraan lebih berharga daripada Kewirausahaan; Berpikir Strategis, Bertindak Demokratis; Mengetahui Akuntabilitas Bukan Hal Sederhana; Melayani Ketimbang Mengarahkan; Menghargai Manusia, Bukan Sekedar Produktivitas)

\subsection{Inovasi Pelayanan Publik}

Inovasi diartikan proses dan/atau hasil pengembangan pengetahuan, pengalaman, keterampilan menciptakan atau memperbaiki produk baik jasa maupun barang, proses, metode yang memberikan value secara signifikan. Inovasi bidang pelayanan public diartikan sebagai cara baru atau ide kreatif teknologi pelayanan bisa juga memperbaharui teknologi pelayanan yang sudah ada atau menciptakan penyederhanaan, terobosan dalam hal prosedur, metode, pendekatan, maupun struktur organisasi dan manfaatnya mempunyai nilai tambah kualitas maupun kuantitas pelayanan. Inovasi tidak mengharuskan penemuan baru dalam pelayanan publik, tetapi merupakan pendekatan baru sifatnya kontekstual, tidak terbatas gagasan dan praktik, dapat juga berupa hasil perluasan maupun kualitas yang meningkat pada inovasi sebelumnya.

$$
\text { Robbins (1994) lebih }
$$

memfokuskan inovasi pada : 1) Gagasan baru yang merupakan olah pikir mengamati fenomena yang terjadi dapat berupa penemuan gagasan pemikiran, sistem, ide sampai pada gagasan mengkristal; 2) Produk maupun Jasa sebagai hasil lanjutan gagasan baru yang merupakan tindak lanjut berbagai kajian, penelitian dan aktivitas percobaan melahirkan konsep konkret bentuk jasa dan produk yang siap diimplementasikan dan dilakukan pengembangan; 3) Upaya Perbaikan yang merupakan usaha sistematis penyempurnaan dan perbaikan terus menerus buah dari inovasi tersebut manfaatnya dapat dirasakan. Inovasi berhubungan dengan Ide-Ide baru yang bermanfaat dan sifat keterbaruannya mempunyai nilai, namun tidak berarti apa-apa bila tidak diikuti kehadiran dan nilai kemanfaatannya.(David Albury, 2003). 


\section{Metode}

Paper ini menggunakan metode studi pustaka yaitu mengumpulkan data, informasi, dengan menelaah jurnaljurnal penelitian, buku-buku referensi, literature-literatur, serta sumber-sumber terpercaya baik tulisan maupun digital yang berhubungan dan relevan dengan topic penulisan.

\section{Pembahasan}

Pemerintah Kota Bandung memiliki banyak inovasi dalam memberikan Pelayanan Publik dalam menghadapi era revolusi industri 4.0. Pelayanan Dinas Penanaman Modal dan Pelayanan Terpadu Satu Pintu (DPMPTSP) Kota Bandung mengembangkan pedoman pelayan publik berbasis elektronik melalui layanan online dpmptsp.bandung.go.id yang memberikan kemudahan kepada warga untuk mengajukan beragam perizinan, diantaranya, HAYU, Kredit Melati, aplikasi Gadget Mobile Aplication for License (GAMPIL), Kredit Mesra. Selain dipermudah melalui perijinan online (layanan dan website resmi), memungkinkan berkas permohonan dijemput oleh petugas dan mengantarkan output ijin/non ijin ke kantor atau ke rumah pemohon melalui pos.

Dinas Pendidikan Kota Bandung melakukan seleksi calon kepala sekolah dilakukan dengan "Si Kasep", sebuah inovasi seleksi para guru yang potensial menjadi kepala sekolah. Si Kasep merupakan aplikasi Seleksi Kepala Sekolah. Digunakan sebagai kanal pendaftaraan administrasi online. Seleksi dimulai dengan pendaftaran online, seleksi administrasi, dan seleksi akademik. Hal ini dilakukan sebelum kandidat diikutsertakan dalam Diklat kandidiat kepala sekolah. Guru mengajukan sendiri, atau rekannya yang memiliki potensi, dengan atau tanpa memiliki rekomendasi dari kepala sekolah. Bagi Guru yang diusulkan rekan/kolega/sejawat atau pun mengusulkan sendiri belum memiliki rekomendasi kepala sekolah, kandidiat dibahas kepala sekolah dan tim seleksi terkait sehingga mendapatkan rekomendasi, dan kesempatan tidak hilang karena ada 'bottleneck'.

Mang Udin yang merupakan singkatan dari Mangga Urus Identitas Kependudukan, dan Bi Eha akronim dari Bisa Euy Hebat, merupakan inovasi pemerintah dalam mensukseskan masalah-masalah kependudukan baik administrasi, akurasi data terkait data baru lahir sampai data kematian. Mang udin dan Bi Eha merupakan inovasi yang dilakukan oleh Dinas Kependudukan dan Pencatatan Sipil Kota Bandung.

Kelurahan Sukaraja, Kecamatan Cicendo meluncurkan Sajadah (Sampah Jadi Banda Bila Dipilah), yaitu program di bidang lingkungan mengurangi kuantitas sampah, mengelola sampah dimulai dari rumah tangga bertujuan agar perilaku warga dan lingkungan 'zero waste', sehingga wilayah menjadi tidak hanya bersih tapi sejahtera karena sampah bernilai ekonomi setelah diolah.

Pemerintah Kota

(Pemkot)

Bandung yang menggandeng 8 bank meluncurkan Bandung Smart Card (BSC) yakni : Bank Mega, BRI, BTN, BCA, Bank BJB, Bank Woori Saudara, dan Bank Mandiri berintegrasi dalam satu kartu untuk pembayaran non-tunai dalam koordinasi BI (Bank Indonesia). BSC merupakan wujud komitmen Pemkot Bandung dalam mendukung Gerakan Transaksi Non Tunai yang digagas Bank Indonesia. Dengan satu kartu, warga tidak lagi menggunakan uang tunai untuk bertransaksi keuangan. Kartu pintar dimanfaatkan untuk bertransaksi pelayanan publik. 
Program Gope TMB, tarif didapat bagi pengguna e-tiket/tap Bandung Smart Card lebih cepat dan praktis untuk transaksi massal non tunai, sehingga masyarakat beralih dari menggunakan kendaraan pribadi menjadi menggunakan transportasi public dan kesadaran dalam menggunakan transportasi public semakin meningkat. TMB Gope menggunakan kartu Tap Cash (BNI) dan kartu Brizzi dari BRI dengan menempelkan kartu transaksi selesai. Program dari Pemerintah Kota Bandung ini ikut mensukseskan pemerintah pusat dalam program gerakan non tunai.

Dinas Perpustakaan dan Kearsipan (Dispusip) Kota Bandung menelurkan program baru bernama Lembur Perpustakaan. Program ini untuk mengakselerasi Program Gerakan Maca Sauyunan (Gemas). Lembur Perpustakaan diarahkan menjadi wisata literasi bagi masyarakat. Pemkot Bandung melalui Dispusip Kota Bandung berkomitmen kuat meningkatkan minat baca masyarakat. Hal tersebut sebagai solusi rendahnya peringkat baca Indonesia yang berada di posisi 60 dari 61 negara pada tahun 2016. Lembur Perpustakaan menjadi wisata literasi bagi masyarakat. Literasi tidak hanya tentang buku, namun juga kemampuan untuk mengakses dan mengomunikasikan informasi, serta keberaksaraan. Contoh Lembur Perpustakaan yang sudah mulai tumbuh berkat kolaborasi masyarakat, yaitu Cibunut, edukasi literasi dilakukan melalui berbagai cara, mulai dari mural hingga aktivasi kegiatan masyarakat. Di Cibunut, semua kegiatan tidak lepas dari literasi. Ada gambar literasi mural, aktivitas, diskusi, salah satu bentuk komunikasi literasi. Sedangkan wilayah yang mulai berkembang antara lain Rancasari dan Cinambo. Pendidikan literasi di dua lokasi itu sedang tumbuh dengan cukup baik. Keduanya melaksanakan aktivasi literasi sesuai dengan karakteristik wilayahnya. Dengan semakin banyaknya Lembur Perpustakaan yang menawarkan aktivitas bertema literasi, dapat mendongkrak kunjungan wisata ke tempat-tempat tersebut.

Aplikasi IndoHub, aplikasi IndoHub terhubung dengan kamera CCTV Area Traffic Control System (ATCS) Kota Bandung, IndoHub juga terkoneksi dengan sistem tanggap darurat Kota Bandung. Terdapat koneksi dengan Dinas Kesehatan (Dinkes) dan Dinas Kebakaran dan Penanggulangan Bencana (Diskar PB). Dengan aplikasi ini, warga dapat mengakses layanan Layad Rawat yang dikelola oleh Dinas Kesehatan. Selain itu juga bisa menghubungi layanan di Diskar PB Kota Bandung. IndoHub berada di bawah pengelolaan Dinas Komunikasi dan Informatika (Diskominfo) Kota Bandung. Berbagai layanan di lintas dinas dapat menggunakan platform ini untuk mempermudah masyarakat mengakses layanan. IndoHub menjadi semacam portal informasi publik bagi warga Bandung. Aplikasi ini menyampaikan berbagai informasi public. Publik bisa mengakses semua jenis layanan atau informasi baik tentang harga, kegiatan, open data, dan informasi-informasi lainnya Layad rawat dan call center. Berbagai informasi dapat dengan nyaman dan mudah dinikmati oleh masyarakat.

Ur-Scape, Aplikasi Manajemen Tata Ruang untuk Tingkatkan Kualitas Perencanaan Kota yang bersifat open source mendukung perencanaan ruang sehingga pemerintah kota bandung memiliki basis data spasial terintegratif berkaitan tata ruang. Ur-Scape membantu pembangun kota baik pemerintah, komunitas maupun swasta 
meningkatkan kualitas desain dan perencanaan tata kota. Aksesibilitas, kerentanan kota, penyebaran penduduk, kulitas lingkungan, kesehatan kota, lapangan pekerjaan, kesesuaian tata ruang kota dapat diketahui oleh Pemerintah Kota Bandung. Tampilan antar muka yang mudah untuk sebaran data dan data-data akurat se-Kota Bandung bisa didapatkan oleh Pemerintah, bekerja dengan menggabungkan, mengumpulkan, mengolah data geospasial semua dilakukan secara sistematis. Interaksi data dan visualisasi data secara intuitif bisa digunakan sebagai platform komunikasi jajaran perangkat daerah.

"Street Library", inovasi
perpustakaan jalur-jalur pedestrian di sekitar Kota Bandung hadir mendekatkan masyarakat pada buku, sebagai upaya meningkatkan literasi. Kualitas literasi berdampak buruk pada sosial masyarakat dan berpengaruh terhadap sumber daya manusia. Upaya meningkatkan warga mencintai buku dengan menyebar 100 street library berupa lemari kayu menyerupai Bandros tersebar di pusat kota.

Anjungan Terima Mandiri Beras, warga miskin memperoleh beras premium menggunakan kartu diperuntukkan warga kurang mampu sehingga terlindungi dengan program Raskin. Setiap ATM beras 75 kepala keluarga dapat dilayani dengan memperoleh $10 \mathrm{~kg}$ beras setiap keluarga, bertujuan agar penerima manfaat memperoleh materi dan nasihat dari pemuka agama di tempat Ibadah, selain itu sengaja ditempatkan di tempat Ibadan untuk meminimalisir penyalah gunaan bantuan. ATM Beras mendorong warga Makin Agamis. ATM Beras dihadirkan di Masjid, dengan hadirnya ATM Beras dapat semakin memakmurkan masjid sebagai tempat ibadah. Warga Kota Bandung yang berhak menerima Bantuan tepat sasaran. Bukan hanya bantuan lahiriah saja tapi memotivasi warga untuk dekat dengan tempat ibadah, jika warga semakin dekat dengan tempat Ibadah maka kondisi keamanan dan ketertiban Kota Bandung terjaga.

Sentra sepatu Cibaduyut merupakan salah satu ikon Kota Bandung. Setiap hari, kawasan yang berada di Kecamatan Bojongloa Kidul ini memproduksi ribuan pasang sepatu. Namun demikian, gempuran persaingan pasar yang semakin ketat menjadi tantangan bagi para pelaku industry di Cibaduyut. Pemerintah Kota Bandung dalam selalu mendampingi warga agar bisa terus memproduksi produk andalan Kota Bandung. Tim kecamatan Bojongloa Kidul telah membuatkan pelatihan, Juga membuat berbagai program inovatif untuk mendongkrak kunjungan ke Cibaduyut dan meningkatkan omzet penjualan. Salah satunya program Kampung Kreatif Sepatu Cibaduyut. Kampung kreatif berlokasi di RW 03 Kelurahan Cibaduyut merupakan pusat aktivitas bengkel sepatu. Letaknya berada di belakang toko-toko sepatu Cibaduyut. Di kampung kreatif, wisatawan dapat menyaksikan secara langsung proses para pengrajin sepatu bekerja. Setiap lokasi memiliki peran yang berbedabeda. Ada yang hanya membuat sol sepatu, mengolah kulit, sampai menjahit sepatu.

Inovasi Pemkot Bandung dalam pelayanan kesehatan kepada masyarakat melalui program Layad Rawat. program layad rawat merupakan inovasi yang sangat bermanfaat bagi masyarakat Kota Bandung, khususnya bagi masyarakat yang tidak bisa datang ke Rumah Sakit. Warga tinggal menghubungi call center di 119. Inovasi Layad Rawat mempermudah dan mendekatkan pelayanan kepada 
masyarakat dengan melibatkan perangkat yang ahli di bidangnya. Di Puskesmas juga telah disediakan kendaraan khusus untuk pelayanan layad rawat yang beroperasi 24 jam, sehingga petugas bisa mendatangi rumah pasien. Program Layad Rawat telah melayani ribuan pasien dengan gejala yang berbeda-beda. Masyarakat bisa lebih cepat mengetahui kondisi kesehatannya sehingga segera diobati. Program ini juga sudah berhasil menjangkau kurang lebih 2900 pasien di Kota Bandung yang sulit untuk datang ke rumah sakit. Dengan kondisi ini, masyarakat bisa secepatnya mendapatkan pengobatan yang tepat.

E-Self Assessment Ta Reporting Application dan Mini Lab Food Security merupakan TOP 99 Inovasi dari Kementerian Pendayagunaan Aparatur Negara dan Reformasi Birokrasi di tahun 2018, kedua inovasi tersebut merupakan pengembangan kota pintar dari komitmen Pemkot Bandung. E-Satria mempermudah pembayaran pajak dan memutus transaksi secara langsung, wajib pajak yang bertemu langsung kerap menjadi pungutan liar. E-Satria mempermudah wajib pajak membayar pajak tanpa mendatangi BPPD, setelah terintegrasi melalui aplikasi, wajib pajak membayar pajak melalui online. E-Satria mengubah budaya dan kebiasaan interaksi petugas dengan wajib pajak, sehingga tidak terjadi interaksi dan komunikasi secara langsung, aplikasi ini digunakan diantaranya untuk wajib pajak hotel, restoran, parkir, pajak penerangan jalan dan tempat hiburan.

Mini Lab Food Security merupakan inovasi kenyamanan dan keamanan konsumen mengkonsumsi bahan pangan dengan cara memfilter sehingga terjaga kemurnian pangan yang akan digunakan oleh konsumen. Konsumen dapat mengetahui kandungan makanan secara cepat melalui halal tes misalnya dalam waktu 60 detik kandungan pangan dapat diketahui. Melalui Mini Lab Food Security bahan pangan 36 pasar tradisional dan 8 perusahaan pasar modern bisa terjamin keamanannya.

\section{Kesimpulan}

Inovasi pelayanan publik merupakan cara baru maupun ide kreatif teknologi pelayanan memperbaharui, penyederhanaan, maupun menciptakan terobosan dalam aturan, prosedur, metode, pendekatan, struktur organisasi sehingga memiliki nilai baik dari segi kualitas maupun kuantitas pelayanan. Tiga hal utama dari inovasi yaitu : Produk dan Jasa; Gagasan baru, dan Upaya perbaikan melakukan penyempurnaan dan perbaikan secara terus menerus yang dapat dirasakan manfaatnya.

dpmptsp.bandung.go.id, aplikasi Gadget Mobile Aplication for License, HAYU, Kredit Mesra, "Si Kasep", Kredit Melati, Mangga Urus Identitas Kependudukanna, Bi Eha, Sajadah (Sampah Jadi Banda Bila Dipilah), Bandung Smart Card (BSC), Gope (500) Trans Metro Bandung TMB. Gerakan Maca Sauyunan (Gemas), Lembur Perpustakaan, Aplikasi IndoHub, Ur-Scape, "Street Library", ATM Beras, Kampung Kreatif Sepatu Cibaduyut, Layad Rawat, Mini Lab Food Security, dan E- Self Assessment Tax Reporting Application merupakan bentuk-bentuk inovasi pelayanan publik Pemerintah Kota Bandung dalam memberikan Pelayanan Publik dalam menghadapi era revolusi industri 4.0.

\section{DAFTAR PUSTAKA}

Denhardt \& Denhardt. 2003. THE NEW PUBLIC SERVICE. London : $\mathrm{M}$. E Sharpe. 
Mulgan, G. \& Albury, D. 2003. Innovation in the Public Sector. Working Paper Version 1.9. October. Strategy Unit. UK Cabinet Office.

Oluwu, Dele. 2002. "Introduction New Public Management : An African Reform Paradigm ?". http:// www.qub.ac.uk/cawp/research/me ehan.pdf.

Osborne, David \& Ted Gaebler. 2003. Reinventing Government. Jakarta: PPM.

Prasojo, Eko. 2003. "Agenda Politik dan Pemerintahan di Indonesia”. Bisnis \& Birokrasi, Vol. XI, No. 1, Januari.

Ratminto, dkk. 2005. Manajemen Pelayanan. Yogyakarta: Pustaka pelajar.

Robbins, Stephen P. 1994. Teori Organisasi, Struktur, Desain dan Aplikasi. Jakarta: Arcan. 